\title{
Cutting the Apron Strings? Cartoon Reflections on the UK EEC Accession from New Zealand Newspapers, 1970-1972
}

\author{
Jessica BAIN, Natalia CHABAN, Sarah CHRISTIE
}

The three decades between 1950 and 1980 represent a vital period in the history of European integration. ${ }^{1}$ During this time, the idea of Europe grew from a functional notion of key unified markets aimed at solving a political problem, to a common market with a queue of hopeful entrants. The growing trend of European integration in this period necessitated a renegotiation of New Zealand's relationship with Europe, and was one of the important contributing factors in New Zealand's realignment of its foreign policy towards the United States and the Asia Pacific region. This paper will examine how this realignment of identity and alliance was represented in the New Zealand (NZ) print news media; more specifically, considering the visual and discursive framing of a key moment in European integration (for NZ and the European Economic Community (EEC) - the accession of the United Kingdom (UK) to the Common Market. While there is extensive research of how the European Union (EU) - a modern-day product of the process of European integration - is perceived in NZ, there has been little work done on historical perceptions of the relationship between the EU (and its precursors) and NZ. ${ }^{2}$

The paper specifically explores the meanings and evaluations of European integration rendered by visual metaphors expressed in political cartoons. While visual analysis of news media remains a relatively understudied phenomenon, research into visual media representations of the EU and its precursors (in media both inside and outside of Europe) is in greater deficit. ${ }^{3}$ Moreover, studies combining political cartoon analysis considering the imagery from a visual conceptual metaphor perspective are scarce. $^{4}$

1. The authors are grateful for the constructive feedback and comments from the reviewers of this paper. We would also like to pay particular thanks to Stuart McMillan, John and Jane Bealing and Henry Connor for their invaluable insights into some of the historical personas present in our cartoons.

2. Since 2002, the National Centre for Research on Europe (NCRE), University of Canterbury, NZ, has conducted a series of studies investigating EU perceptions in NZ's public discourses - in reputable national news media (press and television), among the general public and national decision- and policy-makers. This large-scale research empirically outlines the EU's profile in the eyes of modern NZ society. The NZ study is a part of a larger trans-national study "The EU in the Eyes of AsiaPacific" http://euperceptions.canterbury.ac.nz.

3. J. GREENBERG, Framing and temporality in political cartoons: a critical analysis of visual news discourse, in: The Canadian Review of Sociology and Anthropology, 2(2002), pp.181-198, here p. 181.

4. E. EL REFAIE, Understanding Visual Metaphor: The Example of Newspaper Cartoons, in: Visual Communication, 1(2003), pp.75-95; E. EL REFAIE, Metaphor in Political Cartoons: Exploring Audience Responses, in: C. FORCEVILLE, E. URIOS-APARISI (eds), Multimodal Metaphor, Mouton de Gruyter, Berlin, 2009, pp.173-196; F. YUS, Visual Metaphor versus Verbal Metaphor: A Unified Account, in: C. FORCEVILLE, E. URIOS-APARISI (eds), op.cit., pp.147-172. 
This paper aims to investigate NZ's reactions, as reflected by political cartoonists, to the lead up to, and agreement of, UK membership to the EEC, focusing on the daily coverage of these events in NZ newspapers in 1970-1972. Answering the call for "multilayered perspectives" in the study of historical perceptions of European integration, this paper explores a series of caricatured 'snapshots' of how NZ reacted to the post-war changes on the European continent. ${ }^{5} \mathrm{~A}$ special focus is on portrayals of NZ leaders interacting with their European counterparts, as well as more general images of NZ and Europe in relation to each other. The study starts with an overview of the key moments in the history of EU-NZ relations from the 1950s to the 1970s and outlines a broader survey of NZ's reaction to the events of early European integration as reflected in a wide range of contemporary discourses, including political elites, commentators and academics. It proceeds with a discussion of the theoretical background of visual metaphor analysis and presents the key findings. The paper's discussion aims to assess the contribution of visual imagery to understandings of the $\mathrm{NZ}$ reaction to the EEC's enlargement in the early 1970s - yet another vital clue to understanding NZ's present-day visions on the EU.

It is hoped that this study will add not only an historical insight into the perceptions of integrating Europe from outside its borders (a perspective generally lacking in the growing field of EU external perceptions studies and studies of the history of European integration), but also provide a greater understanding of the EU's historical relevance to NZ and contribute to a successful contemporary dialogue between Europe and NZ. ${ }^{6}$ This historical background is also argued to be helpful in reconstructing a more comprehensive story supporting NZ's present-day perceptions of the EU. A 2012 NZ general public survey (1,000 respondents) revealed a number of ambiguous visions of the EU in NZ. ${ }^{7}$ While trade was named to be the main area for cooperation between the two (indeed, the EU is NZ's third largest trading partner), the EU was ranked as only the sixth most important international partner for NZ. In general, 19\% of respondents perceived the EU in negative terms (vs. 34\% of positive assessments). When asked to describe the EU, respondents chose such descriptors as "modern", "peaceful", "fair" yet "arrogant". Our study hypothesises that the ambiguity and negativity that exists in NZers' current perceptions of the EU can be traced back to the era of the UK's entry to the EEC and the popular images circulated in NZ at that time.

5. Call for papers "Communicating European Integration", Eighth History of European Integration Research Society Conference, March 2012.

6. H. KAELBLE, Welcome address to the 8th HIERS Conference, Humboldt University, Berlin, 2012.

7. Online survey designed by the National Centre for Research on Europe, University of Canterbury, New Zealand, and conducted by TNS in March 2012, within the framework of the research project The EU in the Eyes of Asia-Pacific. 


\section{NZ-EEC RELATIONS: 1950s-70s}

The process of European integration that followed the creation of the EEC in 1957 is an important aspect of world history, and an important part of NZ's own history given the implications of integration in Europe on this small agricultural exporting nation. Yet, there is little research into how NZ reacted and responded to the advent of integration during its early decades. This period saw NZ move from a reliance on Britain as its central economic and political ally to a stronger connection with the USA and Australia (with the formation of ANZUS), as well as searching for a place within the broader Asia-Pacific region. ${ }^{8}$ At the same time, NZ's 'mother country', Britain, was also readjusting its own political and economic priorities in the face of European integration. ${ }^{9}$

A broad survey of both the contemporary literature and commentary on NZ-Europe relations in the 1950s determined that the major European integration events of the 1950s, such as the Schuman Declaration or the Treaty of Paris, were mostly absent from NZ foreign policy discourses during that decade. ${ }^{10}$ This might partly be explained by the then shifting foreign policy focus for NZ after World War II, which moved towards a more geographic focus on its immediate Pacific and Asian 'neighbourhood' (with the USA as a key reference point) ${ }^{11}$ coupled with the prevailing perception amongst NZ's leading opinion formers and academics that there was little likely impact of European integration on NZ providing Britain, as NZ's key European market, remained outside of the evolving European project. ${ }^{12}$

Later NZ historical scholarship mentioned the construction of the EEC only fleetingly (specifically, when it commented on the shift of NZ defence allegiances from the UK to the United States). ${ }^{13}$ However, while some in the academic community (such as Robert McLuskie) noted that there was a small debate within NZ on the possibility of Britain's closer alignment with continental Europe, the prevailing popular reaction especially amongst politicians and other key commentators, was essentially one of support for eventual British entry into the EEC. While these commentators understood scholars' concerns that British entry could produce serious implications for NZ trade, for political leaders particularly, integration was seen as

8. The Australia New Zealand United States Security Treaty.

9. R. KENNAWAY, New Zealand Foreign Policy 1951-1971, Hicks Smith \& Sons, Wellington, 1972; J. SINGLETON, P. ROBERTSON, Economic Relations between Britain and Australasia, 1945-1970, Palgrave, Basingstoke, 2002; see also J. SINGLETON, New Zealand in the Nineteenth and Twentieth Centuries, in: R. WHAPLES (ed.), EH.Net Encyclopedia, 2008, http://eh.net/encyclopedia/article/Singleton.NZ.

10. N. CHABAN, S. CHRISTIE, Re-tracing Europe: Images and Perceptions of the EU in New Zealand History. The 1950s - the Beginning of the Story, in P. WINAND (ed.), The External Relations of the European Union: Historical and Contemporary Perspectives, PIE-Peter Lang, Brussels, 2012, forthcoming.

11. R. KENNAWAY, op.cit., pp.38-39.

12. B. HARLAND, On Our Own - New Zealand in the Emerging Tripolar World, NZIIA, Wellington, 1992, p.28.

13. M. KING, The Penguin History of New Zealand, Penguin Books, Auckland, 2003, p.416. 
important in order to provide for a more politically and economically stable Europe. ${ }^{14}$ Indeed, having only just begun to rebuild itself after intense participation and sacrifice on behalf of Britain and Europe in the two world wars, NZ could see the benefit of a united and peaceful European continent. In fact, a telegram from then NZ Minister of External Affairs to the Secretary of State for Commonwealth Affairs in London in August 1947 highlights this sentiment. The telegram noted that New Zealand

"would be willing to give the fullest consideration to any definite proposals for an economic union in Europe involving possible participation by the Dominions, though [...] we attach great importance to maintaining the special relations between members of the Commonwealth". ${ }^{15}$

However, this limited focus on the developments in Europe by scholars, and the tacit approval of British entry to the EEC by the political elite was to change as it became apparent in the following years that British membership to the EEC was now a probability. ${ }^{16}$ Such a prospect meant potentially critical consequences for NZ particularly in regard to the possible loss of its principal market for key exports like dairy and meat.

In response to likely British accession, two distinct paradigms are apparent within the NZ academic commentary on European integration and NZ's position in the process. ${ }^{17}$ The first of these reactions - evident from the early 1960 s and coinciding with the first discussions of British attempts to join the EEC - focused on a sense of NZ being deserted or forsaken by Britain in pursuing its goal of EEC membership. This group of academics reacted to the UK's probable accession in a highly negative manner, focusing on the more extreme implications for NZ such as market losses, a loss of cultural ties with Britain and a sense of unfair treatment. This position was in contrast to a more rational view which highlighted continuity in relationships between $\mathrm{NZ}$ and Europe and NZ's active role in gaining recognition of its special status and seeking new markets. This more 'pragmatic' attitude developed as a revision of the earlier commentaries, especially once NZ politicians were more actively involved in lobbying for special trade status during the British accession negotiations.

Among the NZ academics writing on this topic in the 1970s, Keith Jackson epitomised the more negative response to the negotiations for British entry: ${ }^{18}$ he chas-

14. R. MCLUSKIE, The Great Debate - New Zealand Britain and the EEC: The Shaping of Attitudes, Decision Research Centre Victoria University of Wellington in association with the NZIIA, Wellington, 1986, pp.8-9.

15. New Zealand National Archives, ABHS W5422 950 157111/14/3/3, part 1, Minister of External Affairs, Wellington to Secretary of State for Commonwealth Relations, Telegram 195, 28.08.1947.

16. R. KENNAWAY, op.cit., p.78.

17. N. CHABAN, S. COLEMAN (CHRISTIE), Re-tracing Europe: Images and Perceptions of the EU in New Zealand History. The 1950s - the Beginning of the Story, The External Relations of the European Union: Historical and Contemporary Perspectives, Monash European and EU Centre, Monash University, Australia, 24-25 September, 2009.

18. His view is especially evident in his commentary of the papers delivered at the 1970 Conference of the New Zealand Institute of International Affairs. 
tised the impact of Britain's entry to the EEC on the NZ economy, arguing that the NZ economy was to be "sacrificed" for Britain's entry in favour of the inefficient farming practices of Europe. ${ }^{19}$ Further, in their 1969 history of NZ, Keith Jackson and John Harré argued that the entry of Britain to the EEC would "wreck the whole basis of the existing [NZ economic] system". ${ }^{20}$ Jackson also talked about the "slaughter of [NZ] dairy farmers" and described the negotiated transitional relationships as a "lingering death" for the NZ economy.

Within this more negative paradigm, NZ was perceived as having little agency in the international environment, and was considered largely defenceless in the face of other, stronger actors. Commentators agonised over the lack of a "direct voice" in the negotiations over issues such as the NZ butter quota and the belief that NZ was reduced to depending on the charity of Britain during negotiations. In contrast to the seemingly ruthless Britons, Jackson stressed the fairness and generosity of New Zealanders who, "as a people" had supported British entry into the EEC, and who were then cruelly repaid by Britain which selfishly followed its own interests: "Britain's main interest is to clear itself of embarrassing entanglements - such as New Zealand - and enter Europe on reasonable terms".

Further, Britain's entry to the EEC was interpreted as a realignment with continental Europe and a rejection of its old Commonwealth partners, values and responsibilities. Jackson, for instance, contended that NZ was entitled to expect Britain to consider its responsibilities to Commonwealth allies, and described Britain as wishing to "cast off many of its old Commonwealth associations in favour of a Euro-centred future". New Zealand's Former Prime Minister Normal Kirk also highlighted the "claim" of NZ on Britain due to its past military services.

However, revisionist academics had a different image of the NZ-Europe interaction during this "apparently never ending soap-opera". ${ }^{21}$ While still recognising that British entry meant turmoil and a turning point for the NZ economy, as well as a more general "anxiety" for the nation, these commentators took a more pragmatic position. Entry for Britain was seen as inevitable and NZ was urged to make the best of it. Thus, the relevant discussion was focused on how NZ should conduct itself during the negotiations and in what ways it could reform its economy to face this new reality and to ensure the best possible outcomes for NZ. In the aftermath of British accession, revisionists such as Richard Kennaway noted that NZ was able to convince Britain, and through them, the EEC countries, to allow NZ a special status that was not granted to other third counties. ${ }^{22}$ Similarly, Lodge noted that despite its relatively limited bargaining power with the EEC, NZ managed to receive concessions in delicate trade areas. ${ }^{23}$ Commentators within this scholarly paradigm viewed $\mathrm{NZ}$ as an active agent

19. K. JACKSON, (ed.), Fight for Life New Zealand, Britain and the EEC, Price Milburn and Company for NZIIA, Wellington, 1970, Introduction, esp. p.11.

20. K. JACKSON, J. HARRÉ, New Zealand, Thames and Hudson, London, 1969, p.112.

21. K. JACKSON, op.cit., pp.7-11.

22. R. KENNAWAY, op.cit., p.72.

23. J. LODGE, The EEC and New Zealand, in: New Zealand International Review, January/Febru$\operatorname{ary}(1976)$, p.11. 
- a nation seeking the best advantage in an unfavourable situation. Stuart McMillan summed up this position stating that:

"What New Zealand accomplished is considerable when the opposition forces are taken into account. N.Z. obtained a legal arrangement with the Community to export food which was politically sensitive in the Community, and has retained a stall in the market place, albeit one which is getting smaller". ${ }^{24}$

The 'pragmatists' also highlighted the continuing positive relationships and dialogue between NZ and Europe and was acknowledged by leading decision-makers. Former NZ Prime Minister Keith Holyoake, during his European tour in 1969, emphasised NZ's special case. In particular, he stressed the positive support NZ had given for European integration and expressed the wish to find common grounds in the discussions on agricultural imports. ${ }^{25}$

It is NZ's pragmatic attitude supporting the development of a strong and peaceful Europe which caught our attention. As discussed above, this positive attitude was expressed by the NZ decision-makers and noted by NZ historians. But the question regarding what specific imagery of the European integration was circulating amongst NZ citizens remains open. Little, if anything, is known about contemporary public opinion from this period, as there were no national surveys undertaken and thus the data does not exist. Our team contends that since the news media are considered to be "first-rate competitors for the number one position as international image-former", ${ }^{26}$ one means by which we can determine public sentiment from this period is by exploring media images of the day. While there are many ways by which public opinion can be formed, ${ }^{27}$ in the case of news on a foreign actor engaged in activities in a location geographically remote from 'home', the news media are argued to have a heightened influence on public opinion formation. ${ }^{28}$ As such, this study proceeds with an analysis of the NZ pictorial press representations in order to gauge a better understanding of how New Zealand responded to the UK's impending accession to the EEC. Specifically, the paper inquires to what degree the political commentary (in the form of newspaper cartoons) reflected a 'pragmatic' paradigm, or, whether visual

24. S. MCMILLAN, How Much Butter?, in: New Zealand International Review, 4(1979), p.28.

25. NEW ZEALAND DEPARTMENT OF EXTERNAL AFFAIRS, New Zealand External Affairs Review, A.R Shearer Government Printer, Wellington, 1969, pp.26-28.

26. J. GALTUNG, M. HOLMBOE RUGE, The Structure of Foreign News, in: Journal of Peace Research, 1(1965), pp.64-91, here p.64.

27. Including, media exposure, interpersonal communication, personal experiences, and education, among others.

28. See for example: W. ADAMS, Mass Media and Public Opinion about Foreign Affairs: A Typology of News Dynamics, in: Political Communication and Persuasion, 4(1987), pp.263-78; D. PERRY, News Reading, Knowledge About, and Attitudes toward Foreign Countries, in: Journalism Quarterly, 2(1990), pp.353-358; P. ROSSLER, The Individual Agenda-Setting Process: How Interpersonal Communication, Egocentric Networks, and Mass Media Shape the Perception of Political Issues by Individuals, in: Communication Research, 2(1999), pp.666-700; M. SALWEN, F.R. MATERA, Public Salience of Foreign Nations, in: Journalism Quarterly, 3(1992), pp.623-632; S. SOROKA, Issues Attributes and Agenda-Setting by Media, the Public, and Policymakers in Canada, in: International Journal of Public Opinion Research, 3(2002), pp.264-285. 
portrayals were typically negative, depicting NZ's reaction to the impending UK accession as a dichotomous battle between the 'Goliath' powers of Europe and NZ's 'David'. This paper now turns to methodological considerations, before presenting an analysis of the cartoons from NZ newspapers in 1970, 1971 and 1972, focusing on these three years specifically, since it was during these years that the UK EEC membership was finalised.

\section{METHOD OF INQUIRY}

This analysis focuses on the NZ print media coverage of a key moment in European integration in the early 1970 s - the lead up to the signing of the UK's accession treaty to the EEC in 1972.29 The daily coverage of European integration was traced in the leading newspapers from the main centres in NZ - the New Zealand Herald (Auckland; North Island), and The Press (Christchurch; South Island). These papers were chosen because of their status (reputable and prestigious), their distribution (between them covering most of the NZ readership at that time) and their stability (continued throughout the decades until the present). As NZ does not have a single daily circulating nation-wide, nor an especially partisan newspaper readership, incorporating these two regionally-significant newspapers is argued to ensure that more than one perspective is researched and that a NZ 'national' response is gauged in a more reliable manner. The cartoons were gathered from published newspapers using Microfiche technology.

In total, 21 EEC-relevant cartoons from both newspapers over the three years were located. Four of these were found in The Press, and the remainder were located in the New Zealand Herald. The majority (12) were published in 1971, presumably as this was the year of the major UK accession negotiations on its EEC membership, which thus warranted particular concern for NZ. Importantly, 17 out 21 cartoons were drawn by Sir Gordon Edward George Minhinnick, a prominent NZ political cartoonist. He was employed by the NZ Herald as a political cartoonist from 1930 to 1976 (and contributed cartoons to the newspaper for more than another decade after retirement). For his services to cartooning, he was awarded the Order of the British Empire in 1950 and was knighted in $1976 .{ }^{30}$ Henk Hilhorst, another leading NZ cartoonist, was the author of two cartoons in The Press. Two remaining cartoons (in The Press) were drawn by William "Bill" Papas, a internationally acclaimed political cartoonist who worked for The Guardian, The Sunday Times and Punch in the 1960s and 1970s.

29. The UK, Denmark and Ireland formally became members in 1973, but the treaty on accession was signed in 1972.

30. I. GRANT, Minhinnick, Gordon Edward George - Biography, in: The Dictionary of New Zealand Biography, updated 01.09.2010, http://www.TeAra.govt.nz/en/biographies/4m55/1. 
Alessandro Bigi et al. define the political cartoon as a "drawing, representational or symbolic, that makes a satirical, witty, or humorous point". ${ }^{31}$ While Ernst Gombrich claims that the power of cartoons comes from compressing historical context and cultural relations within a single visual 'snapshot', which can "re-contextualize events and evoke reference points in ways that a photograph or even a film cannot". 32

While historical studies have long made use of cartoons, studies of political cartoons in news media studies remain scattered and until recently there had been few systematic studies of cartoon framing in news discourses. ${ }^{33}$ Particularly few such studies exist which explore the caricaturing of the EU, despite growing research on the variously mediated identities and images of the Union. One exception which informed this analysis is a work by Elisabeth El Rafaie who comprehensively explored the ways in which metaphors are expressed in the visual mode of political cartoon and compared it with the verbal modes.$^{34}$ Not only this research was positioned within the main tenets of cognitive metaphor theory, but it considered the EU as a topic of cartoons. A useful insight into the analysis of news cartoons in terms of visual metaphors was presented by Liliana Bounegru and Charles Forceville's work on the multimodal discourse of the global financial crisis. ${ }^{35}$ To our knowledge, Bounegru and Forceville's work is also one of the few studies which explore external readings of political cartoons. Importantly, much of the existing literature focuses instead on issues of domestic relevance represented in domestic print news media and cartoons (including El Rafaie's study which examined Austrian cartoons of refugee migration in the context of EU Schengen zone). Thus, our study offers a novel contribution to the field by undertaking an historical study of the visual metaphors expressed by political cartoons commentating on the external process of European integration as viewed from a distance in NZ. ${ }^{36}$ In doing so, it helps to draw additional perspectives towards important social and political issues surrounding the process of economic and political integration in Europe.

31. A. BIGI, K. PlAngGer, M. BOVERA, C. CAMPBELL, When Satire is Serious: How Political Cartoons Impact a Country's Brand, in: Journal of Public Affairs, 3(2011), pp.148-155, here p.153.

32. E. GOMBRICH, Meditations on a Hobby Horse, Phaidon Publications, London, 1963, cited in: A. BIGI, K. PLANGGER, M. BOVERA, C. CAMPBELL, op.cit., p.152.

33. One notable exception is Gamson and Stuart's systematic analysis of the framing of the nuclear bomb in American newspapers. See: W. GAMSON, D. STUART, Media Discourse as Symbolic Contest: The Bomb in Political Cartoons, in: Sociological Forum, 1(1992), pp.55-86.

34. E. EL REFAIE, Understanding ..., op.cit.

35. L. BOUNEGRU, C. FORCEVILLE, Metaphors in editorial cartoons representing the global financial crisis, in: Visual Communication, 10,2 (2011), pp. 209-229.

36. Nb. Bounegru and Forceville define multimodal to be the use of the same conceptual metaphor in different modes. In our case, we explore the different modes to detect the various framings/metaphors. 


\section{RESEARCH PROCEDURES}

Metaphors are interpreted in this study as a cognitive (not solely linguistic) phenomenon. ${ }^{37}$ George Lakoff and Mark Johnson described the essential function of metaphor as the means of "understanding and experiencing one kind of thing in terms of another". ${ }^{38}$ In this paper, the specific definition of visual metaphor has been informed by John M. Kennedy et al. who suggested that any visual depiction can be read as an example of metaphor, "provided that its use is intended to occasion a metaphoric thought". ${ }^{39}$ However, "since all signs are motivated by interest and based on social convention, it is thus not possible to determine unambiguously whether a visual sign is meant to be read "literally' or "metaphorically". ${ }^{40}$ Respectively, then, our analysis of the cartoons incorporated two steps: 1) analysis of the visual semiotics of the image of a cartoon; and 2) analysis of the metaphorical meanings rendered by a combination of the visual semiotics elements of this cartoon. The former step is the key in considering the salience and significance of the identified EU images surfacing in the cartoons by answering:

"the question of representation (what do images represent and how?) and the question of the 'hidden meanings' of images (what ideas and values do the people, places and things represented in images stand for?) [...], what ideas and values do we associate with these depicted people, places and things, and what is it that allows us to do so"?

These elements were then considered in their contribution to the visual metaphor(s) rendered by the cartoon. In either case, this analysis considered the three levels of context in interpreting a visual metaphor, proposed by El Rafaie: 1) the drawing's reference (clear or implicit) to the metaphor theme; 2) pictorial presence of the topic and the vehicle; and 3) the discourse context, in which the association between the topic and the vehicle is common. For example, a cartoon which visually depicts Edward Heath diving into the English channel to swim towards the Common Market, but finds himself tethered to the shore by a post which has the face of his political opponents depicts the metaphor "EEC membership as a journey which has obstacles

37. See, for example, R. GIBBS, The poetics of mind: Figurative thought, language, and understanding, Cambridge University Press, New York, 1994; R. GIBBS (ed.), Cambridge handbook of metaphor and thought, Cambridge University Press, New York, 2008; G. LAKOFF, Metaphor in Politics. An Open Letter to the Internet, 1991, http://philosophy.uoregon.edu/metaphor/lakoff-1.htm, accessed 22 May 2007; G. LAKOFF, M. JOHNSON, Philosophy in the Flesh. The Embodied Mind and its Challenge to Western Thought, Basic Books, New York, 1999; G. LAKOFF, Don't Think of an Elephant: Know Your Values and Frame the Debate, Scribe Publishers, Carlton North, 2005; G. LAKOFF, M. JOHNSON, Metaphors We Live By, University of Chicago, Chicago, 2003; E. SWEETSER, From etymology to pragmatics: metaphorical and cultural aspects of semantic structure, Cambridge University Press, Cambridge/New York, 1990.

38. G. LAKOFF, M. JOHNSON, Metaphors ..., op.cit., p.5.

39. J. KENNEDY, C. GREEN, J. VERVAEKE, Metaphoric Thought and Devices in Pictures, in: Metaphor and Symbolic Activity, 3(1993), pp.243-255, here p.244.

40. E. EL REFAIE, Understanding ..., op.cit., p.82.

41. T. VAN LEEUWEN, Semiotics and Iconography, in: T. VAN LEEUWEN, C. JEWITT (eds), Handbook of Visual Analysis, Sage, London, 2002, pp.92-118, here p.92. 
or challenges". Terminology wise, a metaphor consists of a topic (target domain) and a vehicle (source domain). In the above example, the topic is the UK's accession to the EEC and the vehicle (source domain) is the metaphor of journey and destination. This study is clear that the high context dependency of visual metaphors presents a challenge to this analysis as it "means that their meaning is often implicit and that they tend to be open to quite a wide range of interpretations". ${ }^{2}$

\section{FINDINGS}

A range of visual metaphors were identified in the 21 located cartoons, but several themes and trends emerged. Firstly, there was a split between metaphors which framed the struggle inherent within the cartoon as one between the UK and the EEC, with no reference to NZ at all; and those which framed a struggle between $\mathrm{NZ}$ and the UK, and between NZ and the EEC. Thematically, the visual metaphors typically fell into several broad categories: journeys and travels along a path with obstacles (identified both in terms of the UK's accession negotiations in which the EEC was the 'destination', and in terms of NZ's negotiations with both the EEC and the UK in which a successful outcome for NZ produce was the 'destination'); world politics as a stage for performers; the idea of the EEC as an impenetrable fortress; and inevitable politics as battle metaphors. In addition, there were several metaphors which fell into the category of personification. Finally, the majority of cartoons presented multimodal metaphoric discourses, in that text was used to elaborate and strengthen the visualised metaphor.

Cartoons which excluded any aspect of NZ were in the minority, however there were some which were concerned solely with the UK and the EEC's negotiations. Of these, most drew on personification concepts to frame the UK's discussions on EEC membership. Figure 1 highlights an example of this personification metaphor by depicting the UK and France as reluctant newlyweds being forced into a 'shot-gun' marriage (a point highlighted by the drawing of the former UK Prime Minister Edward Heath threatening 'Brittania' with a shot-gun; taking the metaphor and adding a sense of the literal). In this, France - personified as a 'groom' - is being persuaded (judging from his expression, against his will) by President Georges Pompidou that he does in fact love Britain and want the Union. Thus in a cleverly deployed multimodal presentation, the UK's accession to the EEC 'family' is a marriage, albeit a reluctant one from both sides.

A second cartoon (Figure 2) with no reference to NZ employs the metaphor of a journey towards a destination with obstacles in the road; in this case, the target domain (the 'destination') is EEC membership. In the cartoon, we see Edward Heath diving headfirst into the English Channel, eyes closed and eager to swim towards the Common Market's shores. Heath, however, is tethered to the shore by a rope and post (the

42. E. EL REFAIE, Understanding ..., op.cit., pp.88-89. 
post bears the face of Conservative MP Enoch Powell) and seems unaware that his journey is about to be limited. Powell and Heath had a contentious relationship and Powell was one of the Conservative party's most outspoken critics of British membership in the EEC - and a politician who, at the time, had considerable popularity for his nationalist stance. ${ }^{43}$ The UK's efforts at negotiations on EEC membership are thus rendered as a long swim (journey) with considerable obstacles and challenges to overcome - the post is visually construing the obstacle. The UK itself (through Heath's closed eyes and apparent obliviousness) is presented as contributing to those challenges, by not looking behind him to see what troubles he might yet have to face at home.

The remainder of the cartoon sample had NZ's ambitions as the target domain: they were primarily concerned with NZ's ability to negotiate an agreement with the UK and EEC which would protect NZ interests after British accession. Thematically, the cartoons can be grouped into a number of source domains: world politics as a show on stage, a journey with obstacles in the road, the EEC as a fortress, politics as a battle, and 'others', including personification.

Figure 1: The Press, 18.3.1972, p.17

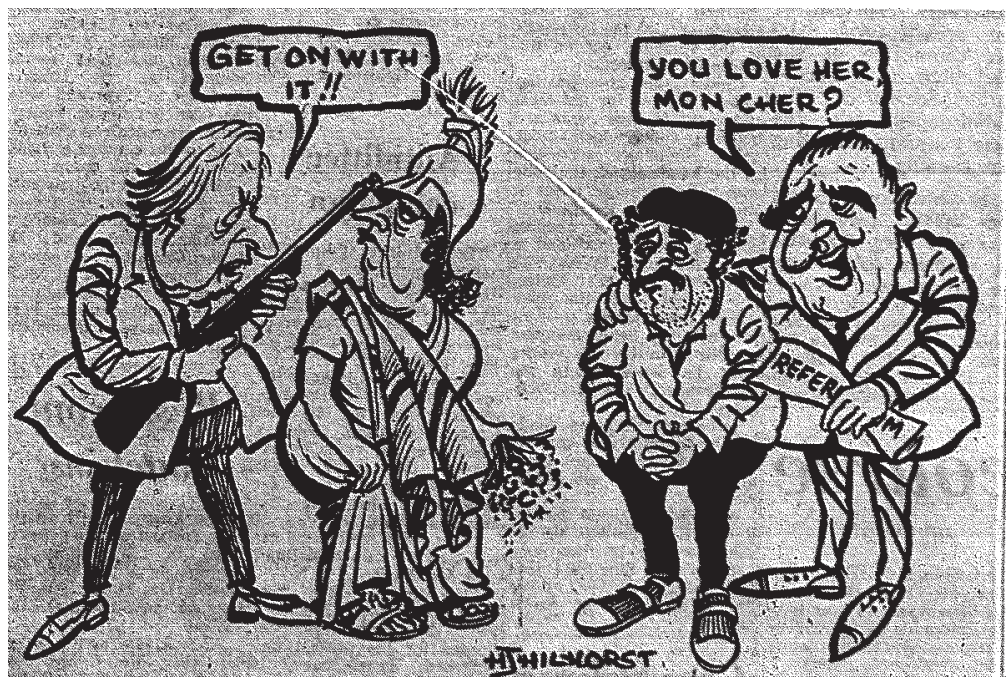

43. P. COSGRAVE, Obituary: Enoch Powell, in: The Independent, 09.02.1998, http://www.independent.co.uk/news/obituaries/obituary-enoch-powell-1143867.html. 
Figure 2: The Press, 25.7.1970, p.13

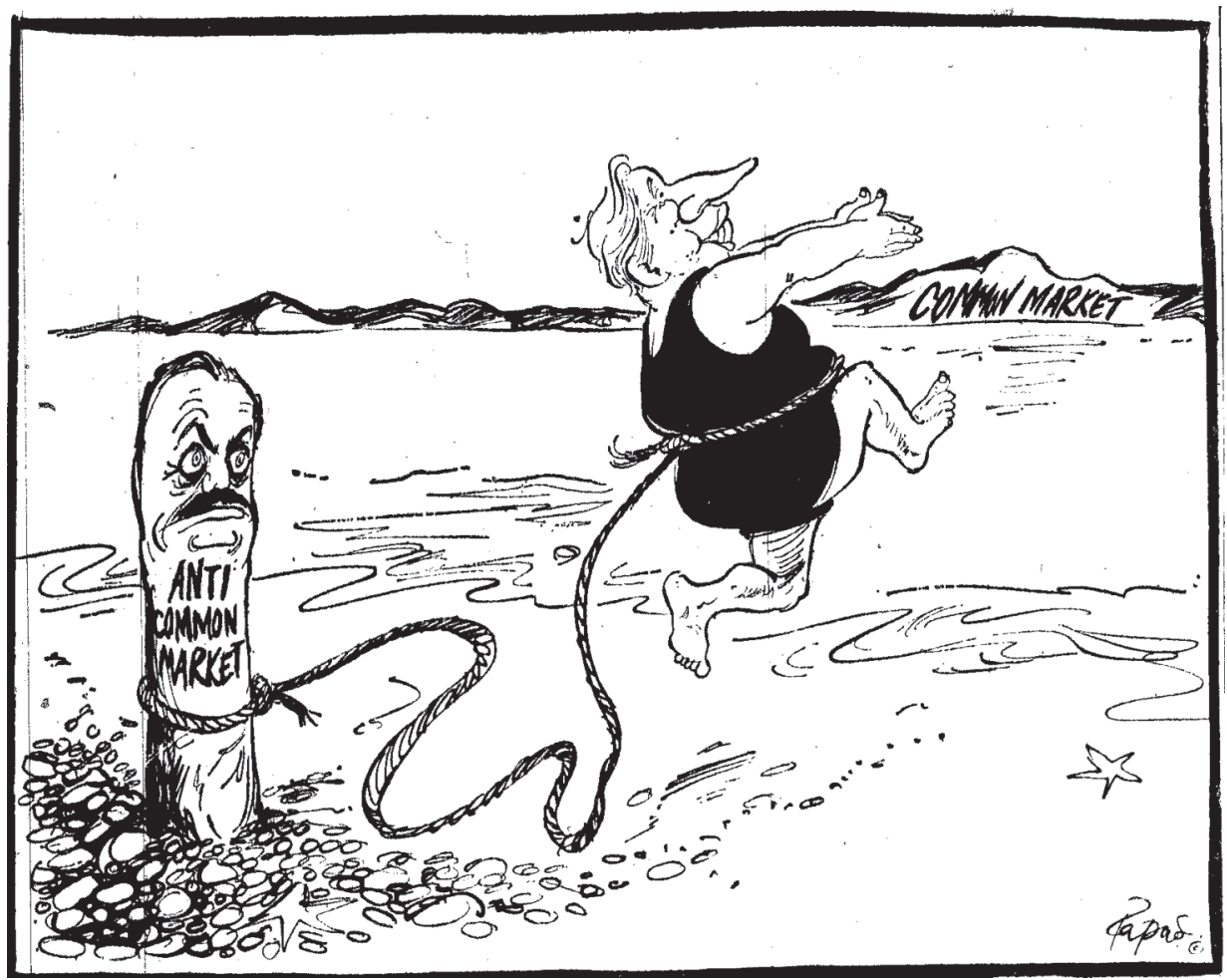

The metaphor of world politics (and negotiations) as a performance on a stage was the most common, though it was variously represented. The specific stage which featured in several of these cartoons was that of a circus 'main stage', on which NZ (or its leaders) were attempting to perform a feat of juggling prowess. Examples of this type of cartoon can be seen in Figure 3 in which NZ's Prime Minister Holyoake is rehearsing his juggling act, before entering the 'EEC arena'. The reference to NZ's negotiating efforts is made by visually presenting Holyoake as the circus juggler and through the image of his juggling 'balls' as apples - one of NZ's agricultural export products (circus here is interpreted as a not very serious, somewhat chaotic and unorganised performance genre, something which has strong negative connotation as mess/disaster in everyday NZ discourses). However, NZ's efforts would appear to be given a poor review, as the 'performer' alongside Holyoake (Norman Kirk, leader of the Opposition and future Prime Minister of NZ) notes 'you won't get anywhere apple juggling these days'. Kirk's comments come across as clear criticism of the 
approach of the Government and the conceptual metaphor thus rendered here in multimodal manner is $\mathrm{NZ}$ as a (poor) performer on stage of EEC negotiations.

Figure 3: NZ Herald, 16.4.1971, s.1, p.6

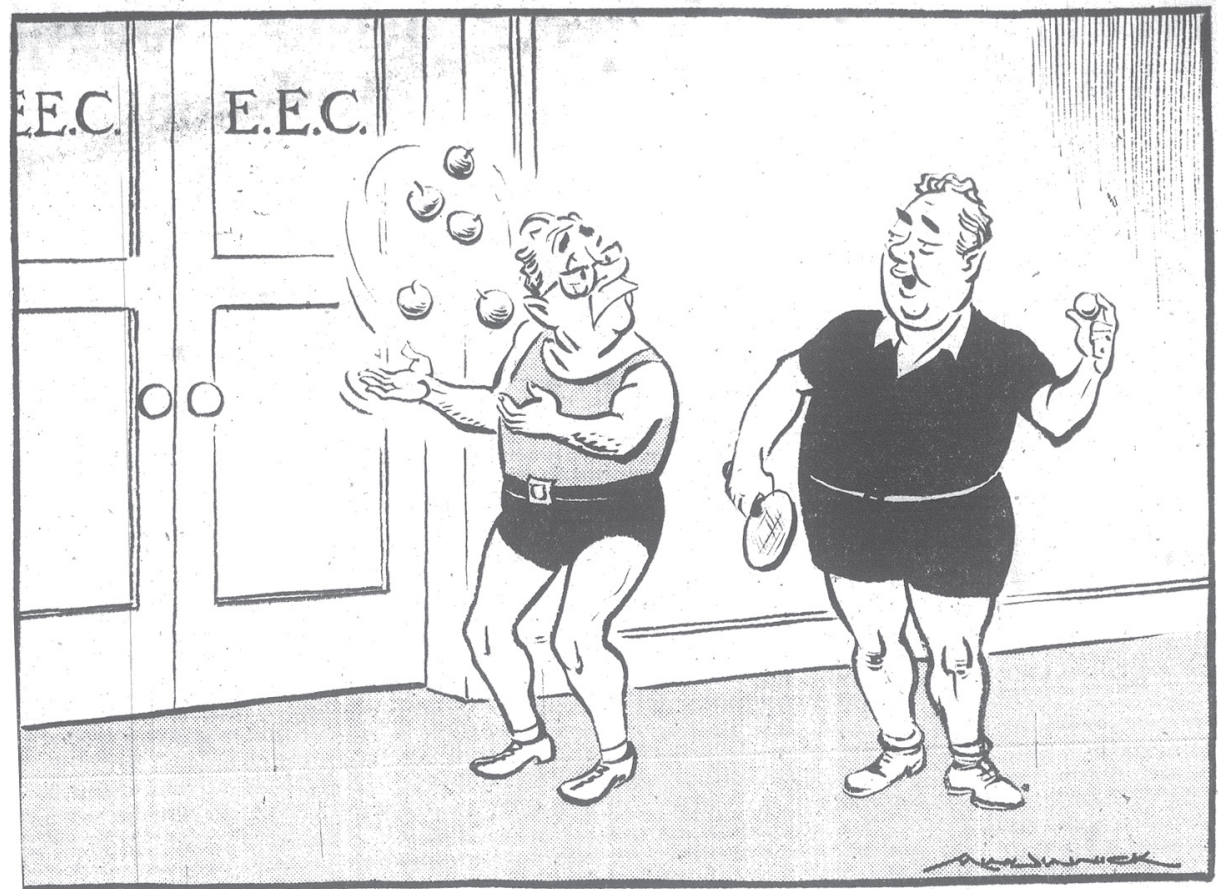

"You'll see! Apple juggling won't get you anywhere these days!"

Similar examples of NZ as a poor performer included Figure 4 in which NZ is pictorially rendered as a country-and-western singer (note the Stetson and guitar), heading off to sing 'NZ's case' to the UK politicians once again, begging them to 'defend' NZ's interests. We know the latter as the text on the performer's 'score' references NZ's national anthem "God Defend New Zealand", except God has been replaced first by the former UK Prime Minister Harold Wilson, and then by the then incoming UK Prime Minister Ted Heath. The various texts tells us that the NZ performer is weary of singing the same song, and that he does not appear to have much popularity with his UK audience. The metaphor here once again, is NZ as a poor performer but this time the stage is negotiations with the UK. The UK too, becomes personified in this cartoon, in which it is rendered as NZ's potential saviour, if it will indeed 'defend' NZ (from the EEC). The EEC itself is not explicitly referenced in the cartoon, either 
textually or visually, but it instead seems to loom like a spectre 'off stage' - it is the threat from which NZ needs defending.

Figure 4: NZ Herald, 1.7.1970, s.1, p.6.

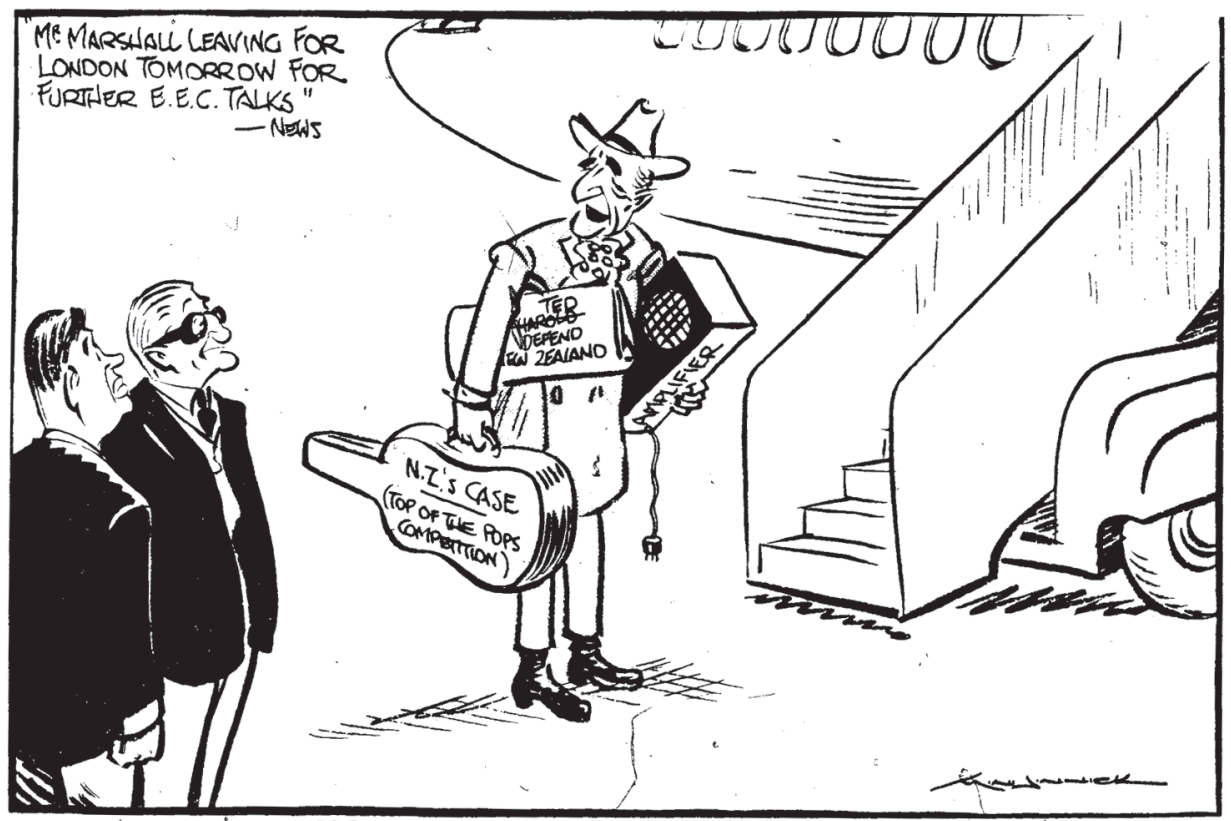

"If I sing it once more, I'm due for a Golden Disc!"

As with the non-NZ cartoons discussed above, in the NZ-oriented ones, there was a regular use of the metaphor journey towards a destination with obstacles in the road. In this case, however, the destination/end-point for $\mathrm{NZ}$ was the successful negotiation of access for NZ goods into the enlarged common market. There were numerous examples of this metaphor, and several quite creative ones. One example (Figure 5) was a rendering of NZ's journey as that of Don Quixote (or in this case, 'Don KeithOake' - referencing Keith Holyoake, the then NZ Prime Minister). 'Keithoake' is depicted riding a horse (the horse itself embodies 'NZ's case') in full jousting attire. He is heading off on one of his infamous adventures (though he is lacking his sidekick, leader of the Opposition Norman Kirk, 'Sancho'), and instead we see only his donkey following along behind. Ahead lie the windmills which in this cartoon represent the EEC, but metaphorically of course they represented giants which Quixote must conquer. In this metaphor then, NZ is a traveller on a journey of adventure, but whose path is impeded by obstacles (the EEC hindering NZ's path towards successful world trade). However, despite Holyoake's 'noble' attire, by rendering him as Quixote, the cartoonist has given the reader cause to doubt his mental acuity and ability to undertake the challenges ahead. Indeed, visually, we see 'Keithoake' with his eyes closed; $\mathrm{NZ}$ is therefore the ignorant and idealistic Quixotic figure, unprepared for the trials ahead. 
Another quite NZ-specific example of the impeded journey can be seen in Figure 6. In this, NZ's efforts at negotiations with the EEC are visually rendered as a mountain to climb - specifically, Mount Everest, the biggest obstacle on earth. The metaphor here is clear: NZ's negotiations with Europe are a journey with the biggest ever obstacle to overcome. The cartoon indicates that this is no ordinary mountain by the pictorial presence of Edmund Hillary himself; the New Zealander who first conquered Everest, talking to Kenneth Cumberland, one of New Zealand's most influential geographers who looked at New Zealand history through landscape, particularly the impact of human settlement and technology. But NZ's efforts are not going as well as Hillary's, and the NZ negotiator (Mr John Marshall) is seen clinging to the cliff of EEC negotiations, dangling only by his fingertips. Mr Marshall (then Minister for Overseas Trade, and future Prime Minister) is thus a rather unsuccessful 'mountainclimber' on this journey. However, the comments by Hillary (in text) tell us that there is some doubt about how precarious Marshall's situation really is, with Hillary saying that he's just pretending to get sympathy. The inference in this cartoon may also be, then, that NZ's negotiators are not really trying hard enough to overcome the vast obstacle of the EEC.

Figure 5: NZ Herald, 6.4.1971, s.1, p.8

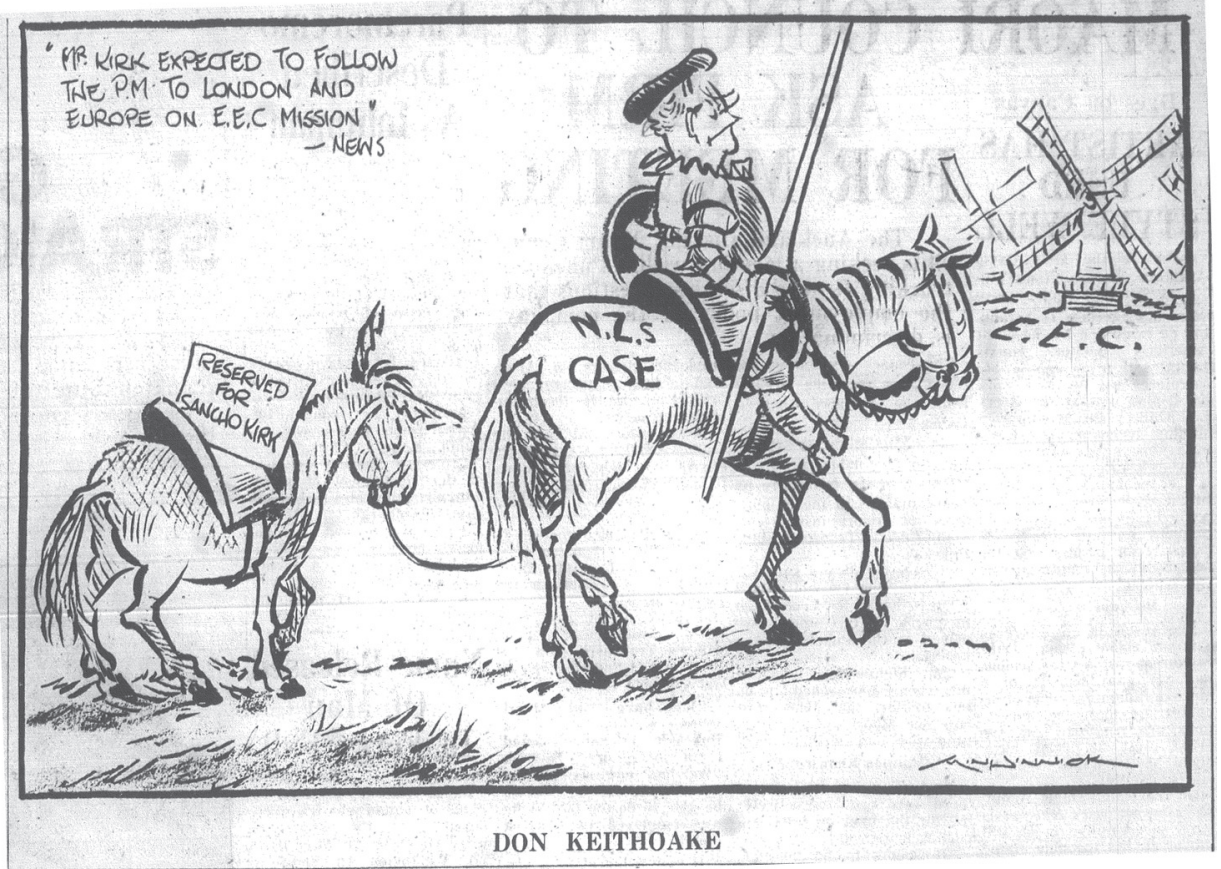


Figure 6: NZ Herald, 11.5.1971, s.1, p.6

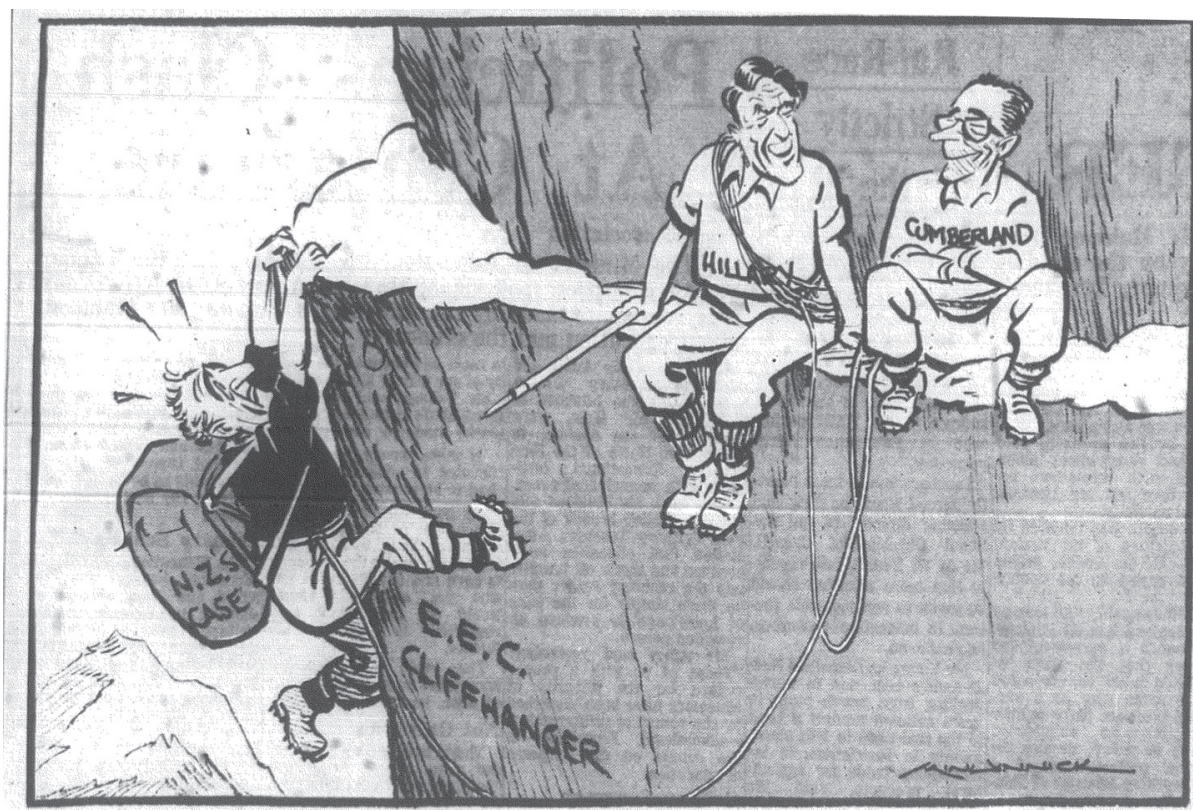

"Pay no attention - he only does it for sympathy!"

A commonly used metaphor for describing the EU in contemporary discourse is as a fortress, and this metaphor also appeared in our historical cartoon analysis. In one such cartoon (Figure 8) the EEC has built a large defensive wall around itself, and it has been followed in the act by the President of the United States Richard Nixon and America's own 'tariff wall'. The US is - and was - another important market for NZ goods, especially lamb, and had recently introduced tariffs on all imports to the US. ${ }^{44}$ With both of its major trade partners becoming increasingly protectionist, NZ (depicted by a NZ politician, Mr Marshall and a flock of sheep, drawing on a specific NZ stereotype) finds itself trapped and faced on both sides by impenetrable fortresses which block NZ trade goods from entering. The metaphor of fortress is furthered by reference to the Berlin Wall, casting both the EEC and USA (in a Cold War era cartoon) into the role of enemies. Thus the EEC is not only a fortress, but clearly is also the villain in this highly negative portrayal of the weak, begging NZ (US) versus the wealthy and well-defended EEC and USA (Others).

44. T. ZEILER, Nixon Shocks the Trade System, Paper presented at the Workshop on Unpeaceable Exchange: Trade and Conflict in the Global Economy, Instituto de Ciencias Sociais, University of Lisbon, 17.07.2010. 
Figure 7: The Press, 20.8.1971, p.3

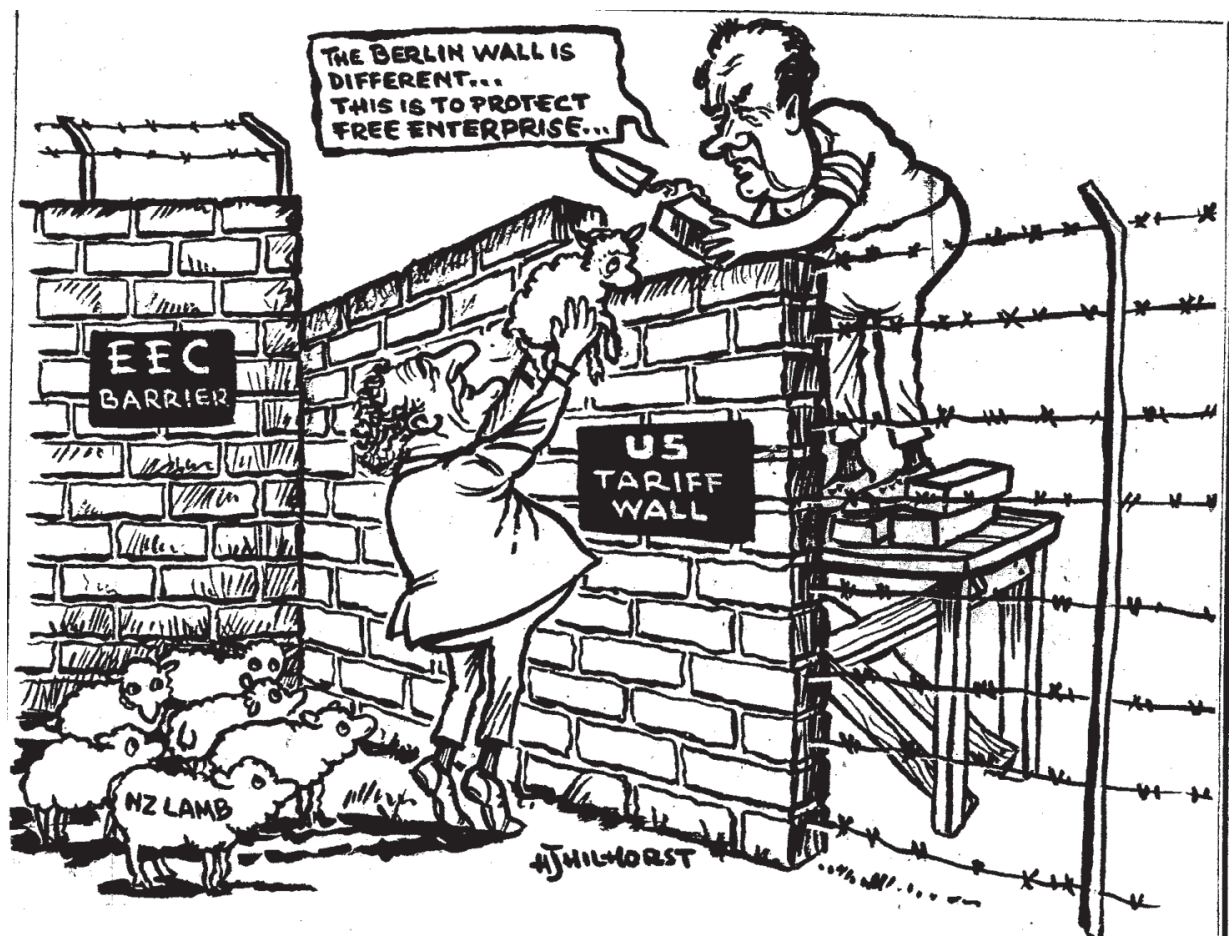

Metaphors of battle or war are commonly used in political discourse; so too, they appeared in our sample. The previously discussed example of Don Quixote could, arguably, also be framed as a cartoon encompassing the battle metaphor, as the deluded Quixote heads into battle with what he believes to be giants. More specific examples were also identified. In one (Figure 8), specific textual reference is made to a military song: "Old soldiers never die, they simply fade away". In the cartoon, we see an image of a NZ farmer and his cow, and the words "old farmers never die, they're simply phased away" appear. Successive images of the farmer get increasingly anxious and smaller, until he and his cow vanish in a puff - they have seemingly been erased. We know from additional text in the cartoon that the EEC is planning to 'phase out' trade with NZ in its future plans. The multimodal message of the cartoon is that NZers are soldiers on the battlefield of the EEC, and soon they will be extinguished by the common market altogether. The allusion to death might seem overly dramatic for trade talks, but with agriculture such a fundamental component of the NZ economy in the 1970s, and the UK and Europe such a vital destination for its products, to have access 'phased out' would indeed be an economic death sentence for NZ industry. There is arguably also a sentiment here, by referencing a military song, that the cartoonist is commenting on Europe's historical track-record of having a casual disregard for NZ's lives and welfare, after such a high proportion of young 
NZers died in successive European wars. In this cartoon, the battlefield is economic trade, but the indifference for NZ welfare would appear to be the same as previous real-world battles.

Figure 8: NZ Herald, 9.6.1971, s.1, p.6

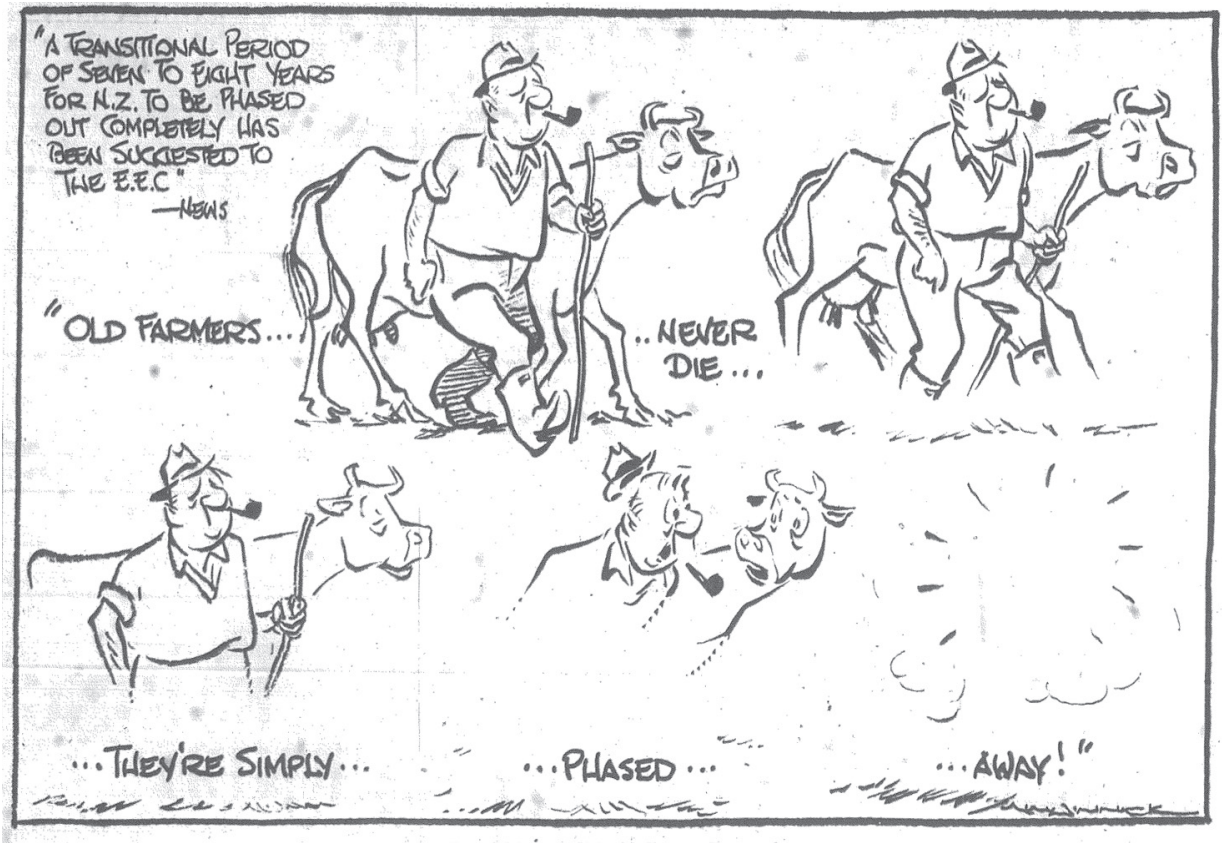

GOING ...GOING ... G-!

In addition to these specific themes, a number of 'other' metaphors were identified which warrant mentioning, but which were not categories in themselves. Whereas personification was noted in two of the three non-NZ cartoons, as discussed above, in the larger sample of NZ-oriented cartoons, personification was relatively scarce, however in one (Figure 9), the EEC agreement with the UK on NZ is a new-born baby. However, the comments from the onlookers are critical of the 'child'. Holyoake's successor, then leader of the Opposition Norman Kirk suggests "Throw it back! There is no meat on it"! One of the leaders of the New Zealand Federation of Labour Tom Skinner (a plumber in the past) claims he "Could have done meself! [sic]" (the use of a phonetically incorrect word may indicate his working class background). His co-leader Jim Knox comments that he "Don't like the look of it"! A generic farmer (the same face was found on several Mininnick's cartoons, with a generic label "farmer" on some $)^{45}$ exclaims "Too small!". The inclusion of the working class and their representatives in this image arguably denotes that it was not just the political elite who were dissatisfied with NZ's 'deal', but ordinary workers too (indeed, Kirk, too,

45. See for example, G. MINHINNICK, All at Sea, 02.03.1971, http://mp.natlib.govt.nz/detail/? $\underline{\mathrm{id}=34213 \& \text { recordNum }=32 \& \mathrm{t}=\mathrm{items} \& \mathrm{q}=\text { Norman }+ \text { Kirk } \& \mathrm{~s}=\mathrm{a} \& \mathrm{l}=\mathrm{en}}$. 
was known for his working class background). ${ }^{46}$ The clear personification metaphor present in this cartoon then, is that NZ-EEC negotiations are child-birth (a physically difficult activity), and the outcome (the baby) is a small, ugly and apparently unwanted child.

Figure 9: NZ Herald, 25.6.1971, s.1, p.6

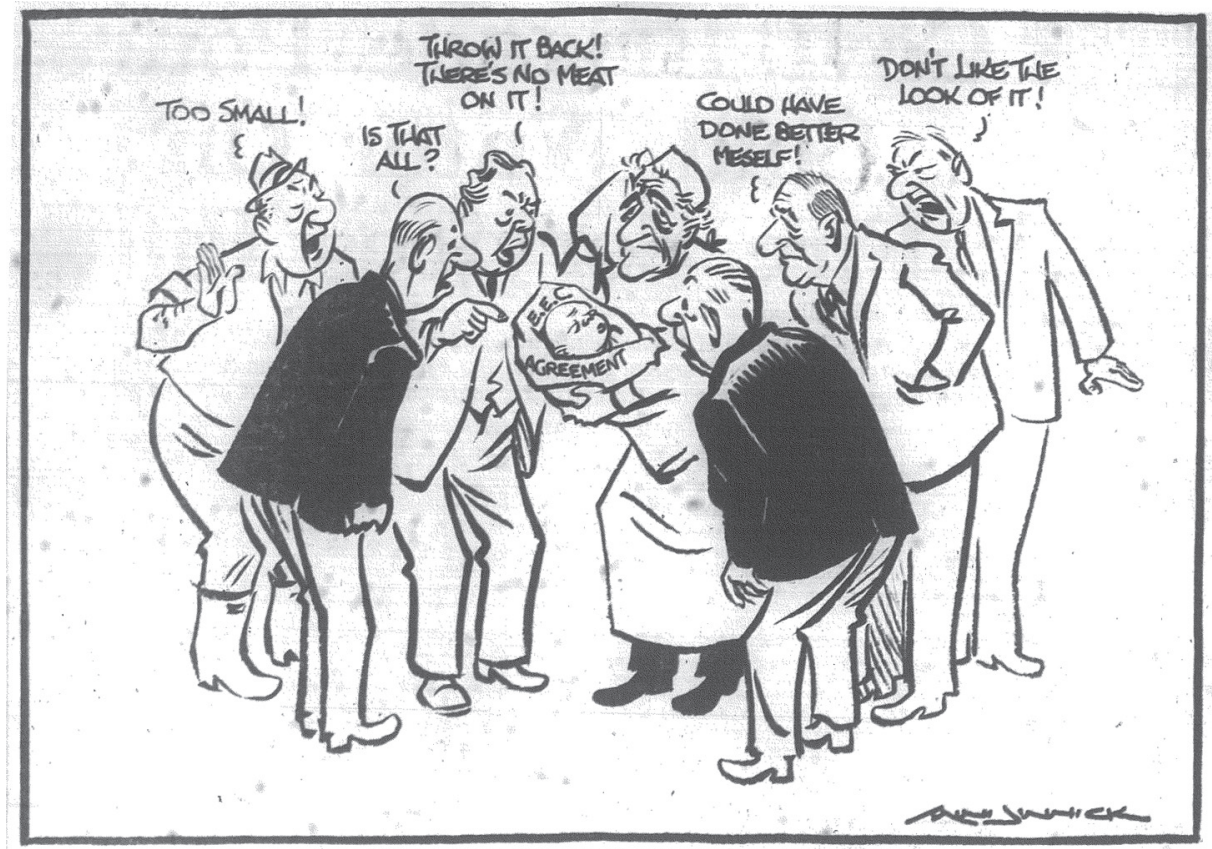

• SPECIAL THANKS TO DOCTOR AND NURSES.

Finally, in the 'other' category, two cartoons drew on metaphors of a more mystical nature. In one cartoon (Figure 10) we see an 'EEC wishing well', from which a NZ politician (Robert Muldoon), visually rendered as a gnome, is trying to fish something. In the cartoon, the gnome sits motionless, apparently waiting for his wish to come true. The metaphor here is that politics are a kind of magic. However, as adults free of the world of fairy-tales, we know the gnome's wish is unlikely to come true. Instead, in the background of the image, we see Holyoake quietly working hard on the garden - his efforts are much more likely to reap rewards, even if they are less

46. M. BASSETT, Kirk, Norman Eric - Biography, in: The Dictionary of New Zealand Biography ..., updated 01.09.2010, http://www.TeAra.govt.nz/en/biographies/5k12/1. 
dramatic. Indeed, the gnome himself is rendered comically and appears as a figure of ridicule, so NZ politicians in the negotiations with the EEC are foolish and ineffective.

Figure 10: NZ Herald, 11.6.1971, s.1, p.6

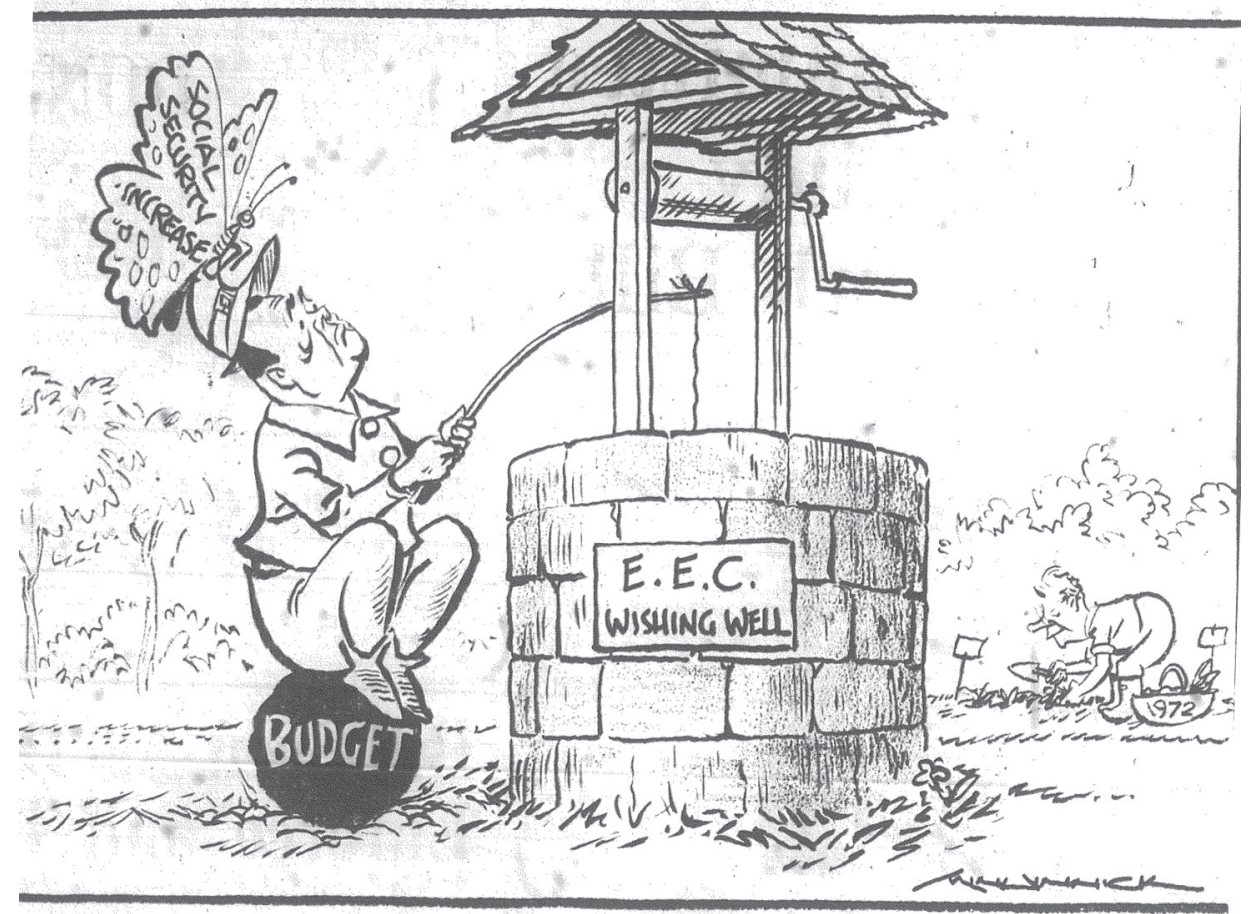

BOULDER, GNOME AND BUTTERFLY

A more sinister metaphor might be identified in Figure 11. In this we see a number of older men in suits. One man stands outside a door, holding another by the legs as if to throw him. A third man walks out the door, about to head into the 'ambush'. The man leaving the meeting has his nose in the air, and looks very pleased with himself, while the man standing outside holding the 'weapon' has a pipe in his mouth (from this and the text we know it is Harold Wilson, former UK Prime Minister). The man leaving the meeting is Ted Heath (judging by the pronounced proboscis). We know the man being held like a weapon is a NZer (Norman Kirk) as he is still furiously penning NZ's views on the UK's EEC treaty negotiations. Presumably Mr Wilson plans to use NZ's claims against Heath's efforts. Thus, at first sight, in this cartoon $\mathrm{NZ}$ is a weapon in UK domestic politics. However, the text accompanying this cartoon makes a further metaphor apparent. The text reference is "More ink throwing". While the cartoon can certainly be seen as a reference to the incident three days earlier when Edward Heath had had ink thrown over him as he entered the building in Brussels for the signing ceremony of the accession treaty, we argue that metaphorically (and combined with the use of the NZer as a 'weapon') the symbolism of ink throwing in 
both cases alludes to Martin Luther's supposed throwing of ink at the devil. Since the target of the ink throwing in this cartoon is Heath who has been negotiating with the EEC, we can see also the metaphor of the UK's negotiations with the EEC as deals with the devil; a sinister metaphor indeed for NZ audiences.

Figure 11: NZ Herald, 25.1.1972, s.1, p.6

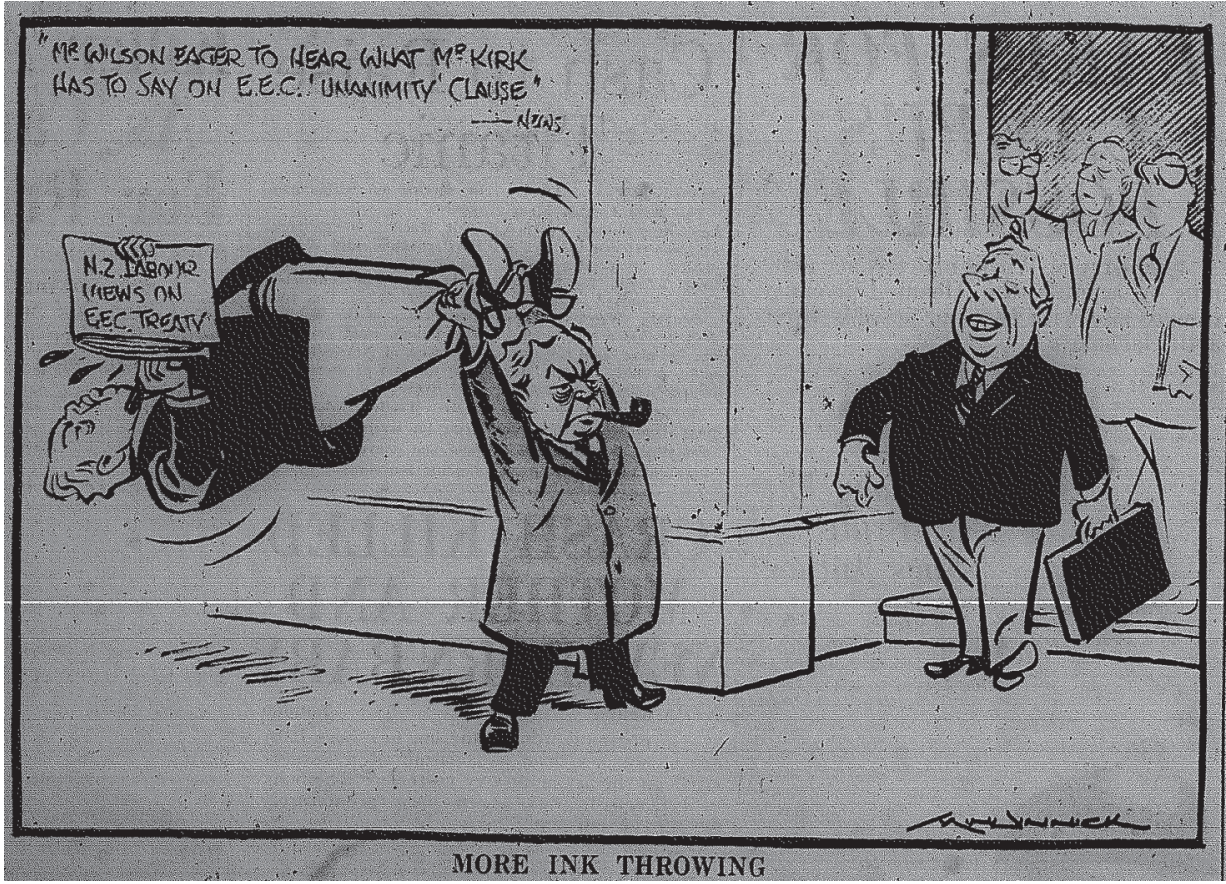

\section{DISCUSSION AND CONCLUSIONS}

This study aimed to understand NZ's reaction to the on-going European integration (and the UK's accessions to the EEC in particular) and investigate which of the two visions - 'abandonment' vs. 'pragmatism' - surfaced in NZ reputable news media discourses in the early 1970s. Specifically, this paper targeted the daily coverage of European integration in 1970, 1971 and 1972 as those were the crucial years of the UK's negotiations towards accession, ending at the end of 1972, after the UK's membership application had been approved. This study's focus on political cartoons of the two leading national newspapers revealed a complicated imagery not easily classified into the 'abandonment' vs. 'pragmatism' paradigm.

Significantly, most of the analysed caricatured 'snapshots' (18 out of 21) portrayed the key events of European integration in the early 1970s in their relation to 
NZ. NZ in those cartoons was either framed interacting with the UK about the latter's EEC accession, or dealing with the EEC directly (yet still in reaction to the UK's membership). This arguably indicates that for NZ society the EEC developments stopped being a remote foreign reality and turned into controversial attention-grabbing events close to home. It also indicates that in understanding of NZ's attitude towards the processes of European integration it is impossible to stay away from Britain: it is a fundamentally 'triangular' relationship between Europe, NZ and the UK, profoundly affected by the UK's membership in the Community.

Despite the controversy in their relations, the UK and its leaders were repeatedly portrayed alongside NZ and it leaders. The relations between the leaders of the two countries varied - from animosity to support - but the UK was never out of the picture. The UK was shown to be actively involved in the search for solutions for NZ in the light of Britain's accessions to the EEC, although these may not have always been to NZ's liking. Even when the UK leaders were not portrayed, British symbols (e.g. the Union Jack) were found in the cartoons that commented on NZ's reaction. As such, our study argues that NZ news media discourses in the early 1970s (at least the eyecatching political cartoons in the main newspapers) did not render a message of NZ's total "abandonment" by the UK. However, frequently, the cartoon framed the UK as an arrogant and charitable benefactor towards NZ - but one who prevented the latter from establishing a direct dialogue with the EEC. In this aspect, the cartoon indeed followed the sentiment of "abandonment" argued by Jackson in $1970 .{ }^{47}$ Interestingly, a cursory analysis of leading Australian historians indicates that a similar sentiment was apparent 'across the ditch'. ${ }^{48}$ The theme of 'abandonment' was also visible in Australian scholars' arguments in relation to the UK's EEC accession. ${ }^{49}$ Given the predominantly negative and/or indifferent perceptions of Australian politicians and public towards the contemporary EU, ${ }^{50}$ it would be interesting in future studies to compare NZ's historical press cartoons to those from Australia to see if similar visual images were also evident.

On the other hand, NZ's attitude towards the unfolding European integration traced in the cartoons did not necessarily correspond to a 'pragmatic' vision of NZEurope relations either. NZ politicians were typically pictured to be ineffective, unskilful and 'blind' about the reality of the common market (almost as if NZ politicians were 'abandoning' or failing their own country). This is probably unfair given NZ was able to negotiate a much better deal with the EEC than other developed nations. ${ }^{51}$ Yet, visual metaphors discovered by this paper reveal that the 1970 s con-

47. K. JACKSON, op.cit.

48. G. BLAINEY, Tyranny of Distance: How distance shaped Australian History, Sun Books, Melbourne, 1966; M. CLARK, History of Australia, Melbourne University Press, Melburne, 1993.

49. J. CURRAN, S. WARD, The Un-Known Nation: Australia after Empire, Melbourne University Press, Melbourne, 2010.

50. See http://www.euperceptions.canterbury.ac.nz/pubs.shtml for additional research by members of this team into contemporary Asia-Pacific Perceptions of the European Union.

51. C. NEIL, New Zealand's butter, sheep, meat and wool exports to the EU-15 since 1960, in: M. GIBBONS (ed.), New Zealand and the European Union, Pearson Education, Rosedale, 2008, p.14. 
temporaries were harshly critical of the NZ leaders' attempts to secure lesser losses for NZ trade, and did not appreciate the achievement by NZ negotiators of a special status not granted to other third counties, ${ }^{52}$ concessions in delicate trade areas, ${ }^{53}$ and a legal arrangement with the EC to export produce which was "politically sensitive in the Community". 54

The visual metaphor tool also helped to discover implicit emotive nuances accompanying the cognitive understanding of the complicated process of European integration. The cartoons published by the leading NZ press carried out a powerful negative assessment towards the concrete NZ and UK leaders, as well as to a more amorphous concept of the EEC. Undoubtedly, this critical sentiment aligned with various groups in NZ society, reinforcing NZ's negative perceptions of the outcomes of European integration for years to come (our team's on-going study of media images has already discovered a dominant negative reaction to all key events of European integration since the mid 1970s and until the end of the 1980s). Future studies will compare how these patterns interacted with each other across the modes (verbal vs. visual metaphors) and across decades (starting from the 1950s) helping shape responses to the present-day EU and NZ-EU relations.

This study, despite its pioneering multidisciplinary nature, has a number of limitations. Firstly, most of the cartoons were located in the New Zealand Herald (17 out of 21) and were drawn by one cartoonist. Yet, with the NZ population being small in the early 1970s (circa 3 million people), ${ }^{55}$ the efforts of the only dedicated political cartoonist to this issue should not be underestimated: as mentioned above, the cartoonist was knighted for his work as a leading political commentator for his contemporaries. We argue that a singular newsmaker publishing his works in a leading news outlet could be an extremely influential image-shaper: Minhinnick's

"work for the country's largest newspaper was widely syndicated and of a consistently high standard; witty rather than barbed, and with a feel for caricature that gave the cartoons an added dimension". 56

We also argue that this finding shows that a pool of informed commentators on European integration in NZ was limited.

In addition, this analysis paid attention only to two key newspapers. Future research will feature a wider media sample as well as include analysis of special periodical publications (specifically, those targeting farming and business communities) to get not only a broader national impression, but also a more narrow view of the groups directly dealings with Europe and having stakes in this relationship. Finally, a similar study in other British Commonwealth states would answer the ques-

52. R. KENNAWAY, op.cit.

53. J. LODGE, op.cit., p.11.

54. S. MCMILLAN, op.cit., p.28.

55. STATISTICS NEW ZEALAND, Demographic Trends 2010, http://www.stats.govt.nz/browse for_stats/population/estimates and_projections/demographic-trends-2010/chapter1.aspx.

56. I. GRANT, The Unauthorized Version - A Cartoon History of New Zealand 1840-1987, David Bateman Ltd, Auckland, 1987, pp.134-135. 
tion if this EEC/UK case is unique or typical for NZ's self attitude. Certainly, this broader view will highlight the finer peculiarities of the portrait painted of European integration printed by visual metaphors of political cartoons in the early 1970s.

William Gamson and David Stuart once claimed that, "among [news] commentators, cartoonists form a kind of peanut gallery, frequently heckling and irreverent, but also given to cheers and whistles of support", going on further to note that in performing this function, "editorial cartoons become a national forum". ${ }^{57}$ Political cartoons can thus be seen to provide a unique and insightful view on the prevailing national attitudes at the time, and arguably, helping to fix attitudes in the future. In the case of our study, responses from the 'peanut gallery' on European integration were mixed with both jeering and cheering, and the NZ-EEC relationship was seen as difficult and fraught with challenges. Yet despite this, there was a sense of the importance of overcoming the obstacles on NZ's journey towards trade with the EEC. Now, more than 30 years on from our study's timeframe and with the current Euro debt crisis, that importance and the need to overcome struggles on the path to dealing with Europe remain, highlighting the prescience and symbolic power with which cartoons can capture a moment in history.

57. W. GAMSON, D. STUART, op.cit., pp.61 and 62. 